\title{
A Note on Translation
}

The Urdu of the Bihishti Zewar is regarded as a model of informal, conversational prose style. It represents the capacity of Urdu from the nineteenth century to appear in a wide variety of prose genres-a new development, for Urdu had been, as a literary language, a language of poetry and tales. Although Maulana Thanawi consulted the women of his family about their problems and customary practices, he did not utilize the dialect of Urdu peculiar to them, known as begamati Urdu. ${ }^{1}$ Nor did he use the Arabicized and more formal style and diction he employed in his scholarly works. ${ }^{2}$ His simple language, which at times still keeps the parallel constructions of poetry, has influenced Urdu prose stylists in the twentieth century, perhaps more than many writers consciously realize. ${ }^{3}$ The goal of this translation has been to approximate Thanawi's fluent conversational style.

The translation is in no sense literal. Urdu has its own logic, as does any language, and can be studied for the cultural principles its structure embodies. To attempt to convey those principles in an English translation, however, simply makes for awkward language and does not in fact afford the opportunity for the serious study of the language that is allowed only by work in the original. For example, there seems to be in Urdu a priority of the object over the actor, making the passive voice very common. Similarly, actors are often acted upon: events and objects impinge on them. It would be inappropriate to replicate this 
structure in English, as it would be inappropriate to imitate the Urdu practice of stringing together events with conjunctions, without indicating the temporal and causal relations commonly specified in English. This use of conjunctions is a result, in part, of the lack of punctuation in Urdu until the past hundred years or so. An early twentieth-century Urdu text, moreover, typically uses only headings, with no paragraphs; thus paragraphs, lists, and much of the punctuation are added here. Urdu also uses direct discourse for reporting conversation far more than English does; I have usually rendered quotations as indirect discourse in the translation.

Urdu has certain repertoires of terms that English lacks, notably terms for expressing hierarchy. There are three ranked pronouns for the second person singular, for example; a common usage is to employ the most respectful, identical with the third person plural, when speaking of an especially revered person. Urdu uses the plural to convey respect, even when speaking of a single person (or, in a practice condemned by opponents of the Deobandis, when speaking of God). Urdu also has double and triple causative verbs to convey the delegation of actions to others. There are many examples of this in the directions for household activities in Book Ten. In general, there is a far greater range for conveying hierarchy in the everyday lexicon of an Urdu speaker. In English, you or I simply "come" or "go"; in Urdu, a worthy person conveys/takes/ brings/places his or her presence. Archaic English does not accurately represent what, in Urdu, is everyday. Some of this hierarchic language is translated literally in sample letters in Book One, where the student is being taught how to make proper discriminations.

One particular term indicating hierarchy is hazrat, a noun based on an Arabic root that means "presence," a term often used as a title or common noun for a respected person. Prefaced by an adjective meaning "lofty," it is used for the saintly or powerful-and was in fact appropriated by the British monarchs as they sought to invent legitimacy for themselves as emperors of India. In this text, it commonly prefaces the names of all prophets, saints, and exemplary people, male or female. It is used for the Prophet Muhammad before his proper name, before the words meaning "messenger" or "apostle," or simply in isolation. In all cases related to him, it is followed by the Arabic prayer of blessing (or its abbreviation), which is discussed below. I have left hazrat untranslated throughout.

I translate the Persian word for God, khuda (often translated as "Lord"), as "God." It is thus not distinguished from the Arabic allah. I make one exception to not using "Lord" for God, an exception that 
reflects an intriguing conundrum in translation and interpretation-the phrase Allah Miyan, translated as "Our Lord and Master" (discussed in the Introduction to the Bihishti Zewar, below).

Along with questions of hierarchy, those of gender require some comment. Unless there is verbal agreement, it is not clear in Urdu whether pronouns are meant to refer to a male or to a female; there is a single word for he/she, his/hers, and so forth. Because it is widely considered unacceptable in English to use the masculine forms as applicable to both sexes, I have sometimes used feminine forms when that seemed appropriate in the context of instruction for women. At other times, I have struggled to find inclusive forms: the section on rules for handling children, in Book Ten, is an example of translation guided by that concern.

Other aspects of the translation are attempts to reflect certain Islamic concepts and conventions. I translate shariat as "religious law," hoping to signal that the Islamic religious law is not law in a Western sense but rather a comprehensive guide to every dimension of human life; it is not definitively codified and is valid quite apart from being administered in a court of law. I also follow a convention in English of capitalizing Prophet when Muhammad is meant, and hence Apostle and Messenger also. I capitalize Companion when referring to a Companion of the Prophet.

Muslims everywhere ideally append a pious Arabic phrase of blessing to the name of every prophet, saint, Companion of the Prophet Muhammad, or other revered person. In English, the phrase, if written, can be obtrusive; moreover, Muslims themselves often use an abbreviation in writing. And sometimes they forget. Generally speaking, I use the full phrase either the first time a name is mentioned or the first time the phrase occurs in a section of text; I usually abbreviate it thereafter. The phrases and abbreviations are as follows: ${ }^{4}$

The superscript sign "s" follows the Prophet Muhammad's name, standing for salla'llahu'alaihi wa sallam, "God's blessings and peace upon him," a phrase used for Muhammads alone.

The superscript sign "a" follows the name of other prophets, standing for 'alaihi's-salam, "On him be peace." Sometimes the phrase is lengthened to "and on our Prophet also."

The superscript sign "rz" follows the names of the Companions of the Prophets. It stands for razi'allahu 'anhu, "May God be pleased with him," or 'anha (her), or 'anhum (them), or 'anhuma (them, dual). 
The superscript sign "rh" follows the names of saints, great religious authorities, and other deceased pious persons. It stands for rahmatu'lla'alaihi, "May God have mercy upon him."

Translations of Qur'anic quotations, prayers, and so forth are shown in an italic bold typeface in the body of the translation, as above, to indicate that they are translated from Arabic, not Urdu. These phrases fill the conversation of the pious. As one Muslim scholar has written, "The soul of a Muslim is like a mosaic made up of formulae of the Qur'an in which he breathes and lives." Some of these phrases are listed below to aid those curious about the original words and implications of these recurrent phrases.

Bi'smi llahu'r-rahmanu'r-rahim: In the Name of God, the Merciful, the Compassionate. After the attestation of faith, this is the most used formula in Islam, including the name of God, Allah, and two characterizing terms derived from the root meaning "divine mercy." It is recited at the beginning of every act and included at the beginning of every written work in order to relate the undertaking to God and thus to sanctify it.

Alhamdu'lillah: Praise be to God. This phrase is used constantly in everyday speech and is the complement of the phrase above. It ends an act, whereas the bi'smi'llah begins it.

Insha'llah: God willing. This phrase is repeated concerning events in the future that cannot be realized without divine consent.

Masha'llah: What God has willed. One uses this phrase at the end of an act or a comment as a reminder that whatever occurs comes from God; it is repeated, for example, when reference is made to one's children or personal experiences. It can be used ironically.

Astaghfiru'llah: I ask forgiveness of God; God forbid! This phrase is used when describing deplorable events.

La haula wa la quwwata illa bi'l-lahi: There is no strength or power but in God. This is also a deprecatory expression repeated when one receives bad news or hears or sees something disagreeable.

Na'uzu bi'llahi: We seek protection by God; God forbid! This phrase is most often used at the prospect of some expression of infidelity ( $k u f r)$.

'Ufi anhu: May God forgive him. A phrase written or spoken after the name of a living person. 
Inna li'llahi wa inna ilaihi raja'un: Truly, we belong to God, and to him we will return. A phrase spoken to express sympathy upon a death or to register sorrow or disgust when one hears something deplorable.

It is difficult in a translation to convey the appearance of the original pages. Urdu texts, including those for publication, are typically handwritten. Even today, readers have little taste for the machine-typed texts that occasionally appear (and are common in Arabic and Persian). Handwriting allows the author or scribe to vary the size and emphasis of script. I have tried to convey this variation through spacing, subtitles, and occasional underscoring.

Explanatory material, commenting on the text, has sometimes been added throughout the translation. Any such editorial interpolations are enclosed in brackets. Urdu and other terms are defined in a glossary. Tables of contents have been added. Bracketed headings do not appear in the original.

The translation that follows consists of the first half of Book One as well as most of Books Six, Seven, Eight, and Ten of the Bihishti Zewar. It is based on the earliest edition available to me, that held by the British Library and catalogued under the name Hafiz Muhammad Ashraf 'Ali (Sadhaura, 1905). Footnotes that appear in that edition are included here at the foot of the text pages. My own notes appear at the end of the volume. 
